(c) American Dairy Science Association, 2003.

\title{
High Pressure Effects on Proteolytic and Glycolytic Enzymes Involved in Cheese Manufacturing
}

\author{
A. S. Malone, C. Wick, T. H. Shellhammer, ${ }^{1}$ and P. D. Courtney \\ Department of Food Science and Technology \\ Ohio State University, Columbus 43210
}

\begin{abstract}
The activity of chymosin, plasmin, and Lactococcus lactis enzymes (cell envelope proteinase, intracellular peptidases, and glycolytic enzymes) were determined after 5-min exposures to pressures up to $800 \mathrm{MPa}$. Plasmin was unaffected by any pressure treatment. Chymosin activity was unaffected up to $400 \mathrm{MPa}$ and decreased at 500 to $800 \mathrm{MPa}$. Fifty percent of control chymosin activity remained after the $800 \mathrm{MPa}$ treatment. The lactococcal cell envelope proteinase (CEP) and intracellular peptidase activities were monitored in cell extracts of pressure-treated cells. A pressure of $100 \mathrm{MPa}$ increased the CEP activity, whereas 200 $\mathrm{MPa}$ had no effect. At $300 \mathrm{MPa}$, CEP activity was reduced, and 400 to $800 \mathrm{MPa}$ inactivated the enzyme. X-Prolyl-dipeptidyl aminopeptidase was insensitive to 5 -min pressure treatments of 100 to $300 \mathrm{MPa}$, but was inactivated at 400 to $800 \mathrm{MPa}$. Aminopeptidase $\mathrm{N}$ was unaffected by 100 and $200 \mathrm{MPa}$. However, 300 $\mathrm{MPa}$ significantly reduced its activity, and 400 to 800 $\mathrm{MPa}$ inactivated it. Aminopeptidase $\mathrm{C}$ activity increased with increasing pressures up to $700 \mathrm{MPa}$. High pressure did not affect aminopeptidase A activity at any level. Hydrolysis of Lys-Ala- $\rho$-NA doubled after $300-\mathrm{MPa}$ exposure, and was eliminated at 400 to $800 \mathrm{MPa}$. Glycolytic enzyme activities of pressuretreated cells were evaluated collectively by determining the titratable acidity as lactic acid produced by cell extracts in the presence of glucose. The titratable acidities produced by the 100 and $200 \mathrm{MPa}$ samples were slightly increased compared to the control. At 300 to $800 \mathrm{MPa}$, no significant acid production was observed. These data demonstrate that high pressure causes no effect, activation, or inactivation of proteolytic and glycolytic enzymes depending on the pressure level and enzyme. Pressure treatment of cheese
\end{abstract}

Received June 12, 2002.

Accepted August 27, 2002.

Corresponding author: P. D. Courtney; e-mail: courtney.25@ osu.edu.

${ }^{1}$ Current address: Dept. of Food Science and Technology, Oregon State University, 100 Wiegand Hall, Corvallis, OR 97331. may alter enzymes involved in ripening, and pressuretreating $L$. lactis may provide a means to generate attenuated starters with altered enzyme profiles.

(Key words: cheese ripening, Lactococcus, peptidase, protease)

Abbreviation key: CEP = cell envelope protease, HPP $=$ high pressure processing, PepX $=$ X-prolyldipeptidyl aminopeptidase, $\mathbf{P e p N}=$ aminopeptidase N, PepC $=$ aminopeptidase C, PepA = aminopeptidase $\mathrm{A}, \boldsymbol{\rho}$-NA $=\rho$-nitroanilide.

\section{INTRODUCTION}

Cheddar cheese maturation involves complex microbiological and biochemical changes. Proteolytic, glycolytic, and lipolytic enzymes can play roles. The appearance of peptides and amino acids as a result of casein proteolysis is essential for achieving a characteristic Cheddar cheese flavor and texture (Fox et al., 1996; Kunji et al., 1996; Law, 2001). The sources of proteolytic enzymes in Cheddar cheese are indigenous milk enzymes, the coagulant, and starter and nonstarter microorganisms.

Chymosin is responsible for the initial hydrolysis of casein during maturation (Fox et al., 1996). Plasmin, a native milk enzyme, also participates. These enzymes produce large and intermediate-sized peptides. The starter culture, Lactococcus lactis, has a cell envelopeassociated proteinase (CEP) and a battery of specific intracellular peptidases. The CEP hydrolyzes the intermediate molecular weight peptides into low molecular weight peptides that are then degraded to free amino acids by intracellular peptidases after importation into the cell or cell lysis (Kunji et al., 1996; Mierau et al., 1996; Christensen et al., 1999). Peptidolysis in cheese does not readily occur until the starter bacteria lyse, which results in the release of intracellular peptidases in the cheese matrix where they have direct access to their peptide substrates (Boutrou et al., 1998). These peptidases hydrolyze low molecular weight peptides to form free amino acids that can participate in further chemical reactions.

Although the majority of lactose in milk is fermented during curd production or removed with the 
whey, the fresh cheese contains 0.7 to $1.5 \%$ lactose that is fermented by the starter organisms during the early stages of cheese ripening (Fox et al., 1996). Therefore, assessment of the lactic acid-producing capabilities of pressure-treated cells is relevant to cheese maturation studies. Lactic acid production by pressure-treated cells is also of interest as a potential means to generate attenuated starter cultures. Attenuated starter cultures are disabled in their ability to ferment lactose to L-lactic acid and can be added along with the normal starter culture to provide an additional source of proteolytic enzymes without affecting acid production rate during cheese making (Fox et al., 1996).

High pressure processing (HPP) is a novel technology that may have many applications in the food industry. Much of the published work involving pressure processing has been aimed at inactivating food pathogens and degradative enzymes (Cheftel, 1992). Yet, substantial evidence exists that low to moderate pressures (100 to $400 \mathrm{MPa}$ ) can activate enzyme activity (Anese et al., 1995; Cano et al., 1997), whereas higher pressures inactivate the same enzymes (Gomes and Ledward, 1996; Goodner et al., 1998). In the case of cheese, HPP has minimal effect on texture and consistency, but if applied early in ripening, may affect cheese-ripening parameters through modulation of enzymatic reactions or viable bacterial populations (Miyakawa et al., 1994; Messens et al., 1999; O'Reilly et al., 2000).

In this study, the effects of high pressure on acidproducing and protein-degrading enzymes of $L$. lactis subsp. cremoris MG1363, and on chymosin and plasmin activities were investigated. Results will help evaluate the biochemical basis for the proteolytic changes and flavor formation during ripening of highpressure treated Cheddar cheese.

\section{MATERIALS AND METHODS}

\section{Sample Preparation and Pressure Treatment}

Bovine plasmin (5 U/ml, Roche Applied Science, Indianapolis, IN) was diluted to $0.3 \mathrm{U} / \mathrm{ml}$ in $1 \%$ Tween20, $0.83 \mathrm{~m} M$ PEG 6000, $50 \mathrm{~m} M$ glycine ( $\mathrm{pH}$ 2.5). Aliquots $(0.24 \mathrm{ml})$ of the diluted plasmin were heatsealed in sterile plastic bags (Nasco, Fort Atkinson, WI) before pressure treatment. Likewise, a commercial chymosin product (Chy-Max Extra, Chr. Hansen, Milwaukee, WI) was dispensed $(0.5 \mathrm{ml})$ without dilution into sterile plastic bags that were then sealed.

Lactococcus lactis subsp. cremoris MG1363 (Gasson, 1983) was grown to late exponential phase at $30^{\circ} \mathrm{C}$ in $\mathrm{M} 17$ broth (Difco, Detroit, MI) with $0.5 \%$ glu- cose (Terzaghi and Sandine, 1975). The cell pellet was collected from $15 \mathrm{ml}$ of culture and washed once in cold, sterile PBS at $\mathrm{pH}$ 7.0, then resuspended in 15 $\mathrm{ml}$ of PBS. The cell suspension was aseptically transferred to a sterile plastic bag that was sealed.

Pressures tested were in 100-MPa intervals from 100 to $800 \mathrm{MPa}$ for $5 \mathrm{~min}$ at $25^{\circ} \mathrm{C}$ in a Quintus High Pressure Food Processor (Flow Pressure Systems, Kent, WA). The pressure transmitting fluid was one part distilled water:one part Houghto-Safe 620-TY (Houghton International, Valley Forge, PA). The initial temperature of the pressure transmitting fluid was controlled to account for adiabatic heating. Setting the temperature of the water-jacketed pressure chamber to the desired process temperature ensured constant process temperatures. Pressure, product temperature, and water-jacket temperature were monitored and recorded in 3-s intervals using a $21 \mathrm{X}$ Micrologger (Campbell Scientific Inc., Logan, UT) connected to a computer running PC208W datalogger support software (Campbell Scientific Inc., Logan, UT). An untreated control was left at $25^{\circ} \mathrm{C}$ at atmospheric pressure $(0.1 \mathrm{MPa})$ for 5 min while each pressure treated sample was being pressurized. Enzyme activities were determined immediately after pressure treatment.

\section{Plasmin Activity Assay}

Plasmin activity was determined using Chromozym PL (tosyl-Gly-Pro-Lys- $\rho$-nitroanilide) as the substrate following the manufacturer's instructions (Roche Applied Science). Release of $\rho$-nitroaniline ( $\rho$-NA) was measured spectrophotometrically at $405 \mathrm{~nm}$ for $30 \mathrm{~s}$. Enzyme activity was calculated as $\mu \mathrm{mol} \mathrm{min} \mathrm{mi}^{-1} \mathrm{ml}^{-1}$ using the molar extinction coefficient at $405 \mathrm{~nm}\left(\epsilon_{405}\right)$ at $10.4 \mathrm{~m}^{-1} \mathrm{~cm}^{-1}$.

\section{Chymosin Activity Assay}

The pressure-treated chymosin samples were diluted $1: 10$ in $0.1 M \mathrm{NaCl}, 0.01 M$ acetate buffer and were assayed by the method of Salesse and Garnier (1976) using a $0.4 \mathrm{mM}$ solution of the substrate $\mathrm{H}$ Leu-Ser- $\rho$-nitro-Phe-Nle-Ala-Leu-OMe·TFA

(Bachem, Bubendorf, Switzerland). The change in molar extinction coefficient at $310 \mathrm{~nm}\left(\epsilon_{310}\right)$ of 0.990 $\mathrm{m} M^{-1} \mathrm{~cm}^{-1}$ was used to calculate the enzyme activity as $\mathrm{mmol} \mathrm{min}^{-1} \mathrm{ml}^{-1}$ (Martin et al., 1981). Activities reported are for the undiluted sample.

\section{CEP Activity Assay}

The CEP assay was performed by the method of Mierau et al. (1996) with some modifications. After 
the pressure treatment, the cell pellet from $1 \mathrm{ml}$ of cell suspension was washed in $80 \mathrm{mM}$ Tris-HCl, $\mathrm{pH}$ 7.0 containing $5 \mathrm{mM} \mathrm{CaCl}$, then suspended in the same buffer containing $2 \mathrm{~m} M$ methoxy-Suc-Arg-ProTyr- $\rho$-nitroanilide (DiaPharma Group Inc., West Chester, $\mathrm{OH})$. The suspension was incubated at $30^{\circ} \mathrm{C}$ and aliquots of the supernatant were monitored for release of $\rho$-NA spectrophotometrically at $410 \mathrm{~nm}$. Enzyme activity was calculated as $\mu \mathrm{mol} \rho$-NA $\mathrm{min}^{-1}$ using $\epsilon_{410}=8.8 \mathrm{mM}^{-1} \mathrm{~cm}^{-1}$. Specific activities were calculated as $\left(\mu \mathrm{mol} \rho\right.$-NA) $(\min )^{-1}(\mathrm{mg} \text { of protein })^{-1}$.

\section{Peptidase Activity Assays}

Peptidase activities were determined by the methods of Mierau et al. (1996) and Vesanto et al. (1995) with some modifications. The cell pellet from $1.5 \mathrm{ml}$ of pressure- or nonpressure-treated samples $\left(\sim 1 \times 10^{8}\right.$ $\mathrm{cfu} / \mathrm{ml}$ ) was washed and resuspended in $300 \mu \mathrm{l}$ of 20 $\mathrm{m} M$ Tris- $\mathrm{HCl}(\mathrm{pH} 7.0$ ). Approximately $0.1 \mathrm{~g}$ of glass beads $(0.1 \mathrm{~mm})$ was added to the cell suspension. The cells were broken using a Mini-BeadBeater (Bio-Spec Products, Inc., Bartlesville, OK) by shaking for three 30 -s intervals at maximum speed. Between each inter$\mathrm{val}$, the samples were placed on ice for $5 \mathrm{~min}$. Cell extracts were recovered after centrifugation.

The enzyme activities were determined at $30^{\circ} \mathrm{C}$ using $0.2 \mathrm{ml}$ of cell extract $\left(0.3 \mathrm{mg} \mathrm{ml}^{-1}\right.$ protein $)$ added to $0.8 \mathrm{ml}$ of $20 \mathrm{mM}$ Tris- $\mathrm{HCl}$ ( $\mathrm{pH} 7.0$ ) containing 0.2 $\mathrm{m} M$ substrate. Each reaction mixture was monitored for release of $\rho$-NA spectrophotometrically at $410 \mathrm{~nm}$ over time. Enzyme specific activities were calculated as described above for CEP activity. X-Prolyl-dipeptidyl aminopeptidase (PepX) activity was evaluated using two substrates, Gly-Pro- $\rho$-NA and Ala-Pro- $\rho$-NA (Christensen et al., 1999). Aminopeptidase N (PepN) and aminopeptidase A (PepA) were evaluated using Lys- $\rho$-NA and Glu- $\rho$-NA, respectively. Aminopeptidase $\mathrm{C}$ (PepC) is also active on these substrates (Christensen et al., 1999), thus PepN and PepA activities were distinguished from PepC by the addition of $5 \mathrm{~m} M$ EDTA. PepN and PepA are metalloproteins that are inhibited by EDTA (Niven, 1991; Exterkate and DeVeer, 1987; Tan and Konings, 1990), whereas PepC is not (Neviani et al., 1989). PepN and PepA activities were calculated as the EDTA-sensitive activity on the appropriate substrate by subtracting the activity in the presence of EDTA from the activity without EDTA. PepC activity was reported by hydrolysis of Lys- $\rho$-NA in the presence of $5 \mathrm{~m} M$ EDTA. Hydrolysis of Lys-Ala- $\rho$-NA was also evaluated. All $\rho$-nitroanilide substrates were purchased from Bachem (Bubendorf, Switzerland).

\section{Protein Concentration}

The protein concentration of each cell extract was determined by the Bio-Rad protein assay (Bio-Rad, Hercules, CA) based on the Bradford method (Bradford, 1976). Bovine serum albumin was the standard. Cell extracts were standardized to $0.3 \mathrm{mg} \mathrm{ml}^{-1}$ protein with $20 \mathrm{~m} M$ Tris-HCl before peptidase assays. Protein concentration was also determined in selected cell extracts by analysis in a Perkin Elmer Series II Nitrogen Analyzer 2410 (Perkin Elmer, Inc., Wellesley, MA).

\section{Lactic Acid Production by Cell Extracts}

Lactic acid production by cell extracts was determined by the method of Miyakawa et al. (1994) with some modifications. Cells were grown to late exponential phase $\left(\sim \mu 1 \times 10^{8} \mathrm{cfu} / \mathrm{ml}\right)$ in $250 \mathrm{ml}$ of G-M17. The cells were washed and concentrated in $20 \mathrm{ml}$ of PBS ( $\mathrm{pH}$ 7.0). The cell suspension was pressure treated in a sterile plastic bag. After the pressure treatment, the cell suspension was sonicated for $10 \mathrm{~min}$ at $4^{\circ} \mathrm{C}$ (Ultrasonic Processor 36800, Cole Parmer, Vernon Hills, IL). Following centrifugation, $5 \mathrm{ml}$ of each cell extract were added to $45 \mathrm{ml}$ of a $1.1 \%$ (wt/vol) glucose solution. The samples were incubated for $1 \mathrm{~h}$ at $30^{\circ} \mathrm{C}$. The percent lactic acid $(\mathrm{g} / 100 \mathrm{ml})$ was estimated by titration with $0.1 \mathrm{~N} \mathrm{NaOH}$ using phenolphthalein as the $\mathrm{pH}$ indicator.

\section{Statistical Analysis}

Data are shown as mean \pm SD and are the results of at least three independent replications of each experiment. Mean comparisons between different pressures for each enzyme evaluated were performed with a one-way ANOVA followed by Tukey's test with $\alpha=$ 0.05 (JMPin, SAS Institute Inc., Cary, NC and SigmaStat 5.0, SPSS Inc., Chicago, IL).

\section{RESULTS AND DISCUSSION}

\section{Chymosin and Plasmin Activities}

Plasmin activity was not affected significantly by any pressure treatment $(P>0.05)$ (Figure 1$)$. Chymosin treated with 100 to $400 \mathrm{MPa}$ did not differ significantly in activity from the control $(P>0.05)$ (Figure 2). At 500 to $800 \mathrm{MPa}$, chymosin activity was reduced with increasing pressure $(P<0.05)$. Approximately $50 \%$ of the control chymosin activity remained after treatment at $800 \mathrm{MPa}$.

Based on SDS-PAGE analysis of pH 4.6-insoluble nitrogen, Messens et al. (1999) concluded that plas- 


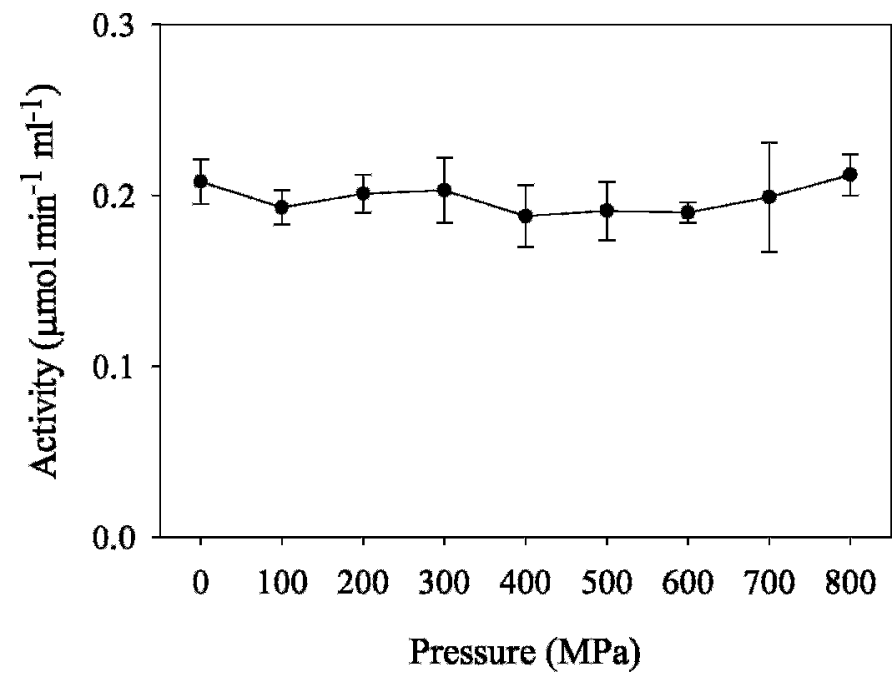

Figure 1. Plasmin activity ( $\mu \mathrm{mol} \mathrm{min}^{-1} \mathrm{ml}^{-1}$ ) after pressure exposure for $5 \mathrm{~min}$ at $25^{\circ} \mathrm{C}$. Error bars represent $\pm 1 \mathrm{SD}, \mathrm{n} \geq 3$.

min and chymosin activities in Gouda cheese were not affected by pressure treatments of 50 to $400 \mathrm{MPa}$ for 20 to $100 \mathrm{~min}$. Scollard et al. (2000) found that plasmin is pressure stable in most systems and is able to hydrolyze $\beta$-casein after pressure treatments up to $700 \mathrm{MPa}$. A treatment of $400 \mathrm{MPa}$ at $25^{\circ} \mathrm{C}$ for $30 \mathrm{~min}$ did not inactivate plasmin in milk (García-Risco et al., 1998). Rennet proteolysis in milk was not affected by $127 \mathrm{MPa}$ for $90 \mathrm{~min}$ (Ohmiya et al., 1987). The data presented here concur with those in the literature, though the medium in which the enzymes were treated, the enzyme assay method, and the duration of pressure treatment differed.

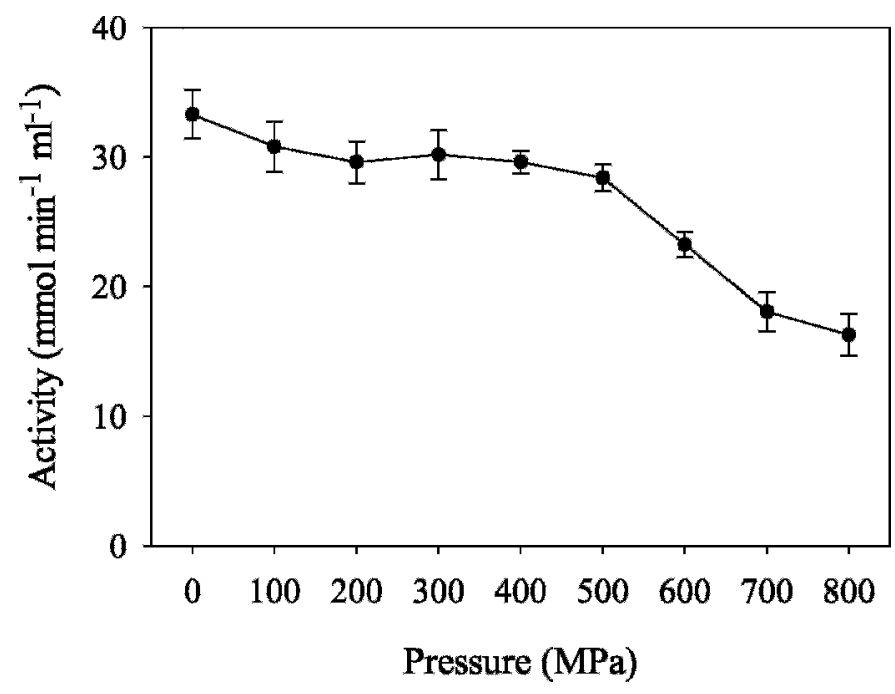

Figure 2. Chymosin activity $\left(\mathrm{mmol} \mathrm{min} \mathrm{m}^{-1} \mathrm{ml}^{-1}\right)$ after pressure exposure for $5 \mathrm{~min}$ at $25^{\circ} \mathrm{C}$. Error bars represent $\pm 1 \mathrm{SD}, \mathrm{n} \geq 3$.

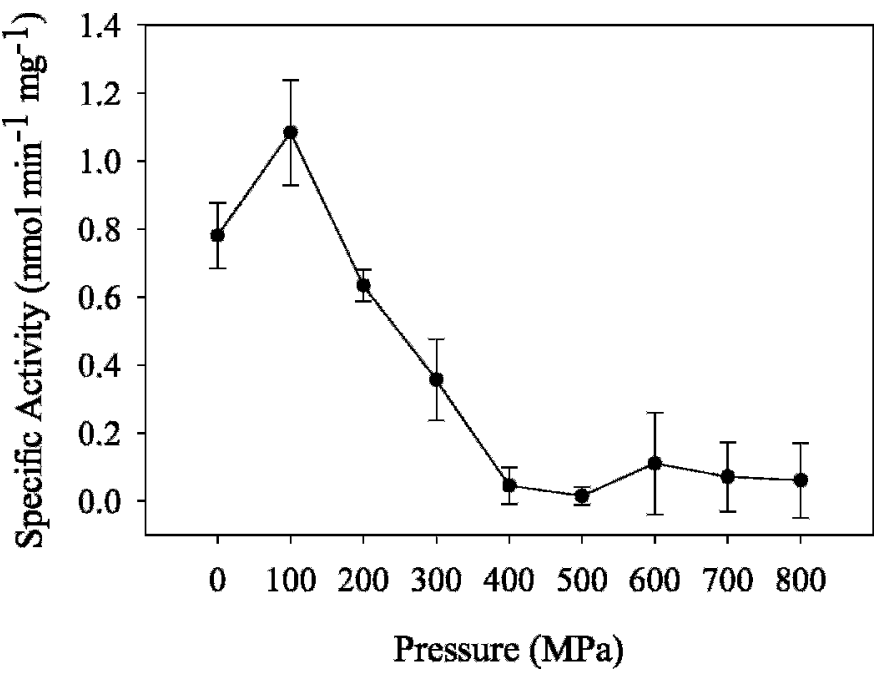

Figure 3. Specific activity $\left(\mathrm{nmol} \mathrm{min}{ }^{-1} \mathrm{mg}^{-1}\right)$ of the Lactococcus lactis MG1363 cell envelope proteinase (CEP) after pressure exposure for $5 \mathrm{~min}$ at $25^{\circ} \mathrm{C}$. Error bars represent $\pm 1 \mathrm{SD}, \mathrm{n} \geq 3$.

\section{CEP Activity}

After exposure to $100 \mathrm{MPa}, \mathrm{CEP}$ activity was significantly higher than at all other pressures, including the atmospheric pressure control $(P<0.05)$ (Figure 3$)$. The 0.1- and 200-MPa samples were not statistically different. The CEP activity was significantly reduced at $300 \mathrm{MPa}$ and was essentially inactivated at 400 to $800 \mathrm{MPa}$. No previous reports of lactococcal CEP activity post-pressurization are available.

\section{Peptidase Activities}

Activities of two broad specificity aminopeptidases (PepN and PepC), a glutamyl aminopeptidase (PepA), and PepX were evaluated in cell extracts after pressure treatment of intact cells. In addition, hydrolysis of Lys-Ala- $\rho$-NA was evaluated. PepN was unaffected by 100 - and $200-\mathrm{MPa}$ treatments compared with the control (Figure 4A). However, at $300 \mathrm{MPa}, \mathrm{PepN}$ activity was dramatically reduced; and at 400 to $800 \mathrm{MPa}$, PepN was inactivated. High pressure had a positive effect on PepC activity (Figure 4B). PepC activity increased with increasing pressure from $0.1 \mathrm{MPa}$ up to $700 \mathrm{MPa}$ and declined at $800 \mathrm{MPa}$. At 400 to $800 \mathrm{MPa}$, PepC activity was significantly increased $(P<0.05)$ compared with the control $(0.1 \mathrm{MPa})$. At $700 \mathrm{MPa}$, a maximum activity of $2.11 \mu \mathrm{mol} \mathrm{min} \mathrm{mg}^{-1}$ was observed, whereas the $0.1-$ and $800-\mathrm{MPa}$ samples had activities of 0.20 and $1.28 \mu \mathrm{mol} \mathrm{min}{ }^{-1} \mathrm{mg}^{-1}$, respectively. PepA activity was not significantly affected by HPP at any level (Figure 4B). 

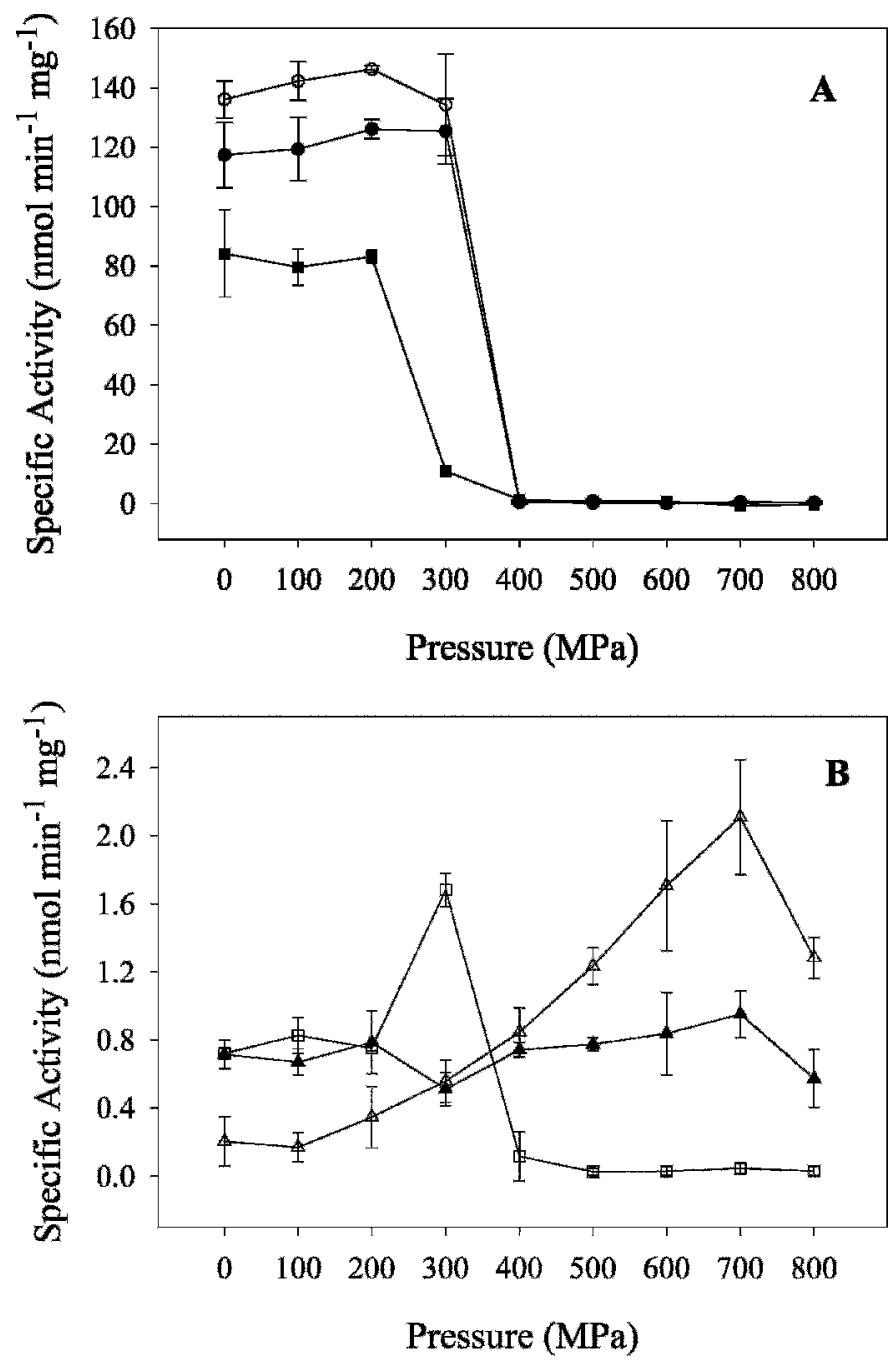

Figure 4. Specific activities $\left(\mathrm{nmol} \mathrm{min}-1 \mathrm{mg}^{-1}\right)$ of intracellular peptidases after pressure exposure of Lactococcus lactis MG1363 for 5 min at $25^{\circ} \mathrm{C}$. Error bars represent $\pm 1 \mathrm{SD}, \mathrm{n} \geq 3$. Panel A: PepX hydrolysis of Gly-Pro- $\rho$ NA $(-)$ and Ala-Pro- $\rho$ NA $(\bigcirc)$ and PepN hydrolysis (EDTA-sensitive) of Lys- $\rho$ NA ( $\mathbf{\square})$. Panel B: PepA hydrolysis (EDTA-sensitive) of Glu- $\rho$ NA $(\boldsymbol{\Delta})$, PepC hydrolysis (EDTA-resistant) of Lys- $\rho$ NA $(\triangle)$, and hydrolysis of Lys-Ala- $\rho$ NA $(\square)$.

PepX was unaffected by $100-, 200-$, and $300-\mathrm{MPa}$ pressure treatments compared with the control $(P<$ 0.05) (Figure 4A). PepX was inactivated at pressures of $400 \mathrm{MPa}$ and greater. PepX activity was examined on two substrates, Gly-Pro- $\rho$-NA and Ala-Pro- $\rho$-NA. Both substrates yielded the same enzyme inactivation profile indicating that activities on two different substrates are affected similarly by pressure treatment.

Hydrolysis of Lys-Ala- $\rho$-NA was unaffected by 100 and $200 \mathrm{MPa}$ and inactivated at pressures of 400 to $800 \mathrm{MPa}$ (Figure 4B). At $300 \mathrm{MPa}$, Lys-Ala- $\rho$-NA hydrolysis was significantly higher $(P<0.05)$ than at all other pressures with double the activity of the nonpressure-treated control. To our knowledge, LysAla- $\rho$-NA hydrolysis by $L$. lactis cell extracts has not been described previously. Release of the chromogenic $\rho$-NA from this substrate could result from dipeptidyl peptidase activity or from two consecutive aminopeptidase reactions, with the second releasing $\rho$-NA from Ala- $\rho$-NA. We cannot distinguish between these possibilities with the present data, although the pressure inactivation profiles suggest that hydrolysis of LysAla- $\rho$-NA is not solely due to the general aminopeptidases, PepC and PepN.

Other researchers have reported inactivation and activation of bacterial proteolytic enzymes by high pressure. Pressurizing $L b$. helveticus cells to $400 \mathrm{MPa}$ at $30^{\circ} \mathrm{C}$ for $10 \mathrm{~min}$ increased aminopeptidase and PepX activities (Miyakawa et al., 1994). In contrast, Casal and Gómez (1999) found reduced aminopeptidase, PepX and dipeptidase activity after a 20-min, 400-MPa treatment of $L b$. casei, whereas no reduction was observed in L. lactis. These studies suggest interspecific variation in pressure sensitivity of aminopeptidases. Differences in pressure application time, pressurization medium, bacterial species, and peptidase assay substrates make direct comparison to the present data difficult. Nonetheless, it is apparent that pressure has different effects on different peptidolytic enzymes within a bacterial strain. Additional studies are required to fully understand any inter-and intraspecific variations in pressure sensitivity of enzymes.

\section{Lactic Acid Production by Cell Extracts}

The glycolytic capacity of pressure-treated cells was assessed by incubating cell extracts with glucose for $1 \mathrm{~h}$ and measuring titratable acidity as percent lactic acid $(\mathrm{g} / 100 \mathrm{ml})$. The titratable acidities of the 100 - and 200-MPa samples were slightly increased compared to the control level of $0.031 \%(P<0.05)$ (Figure 5). In samples treated at 300 to $800 \mathrm{MPa}$, titratable acidities were significantly decreased to 0.006 to $0.008 \%$, indicating a loss in activity of one or more enzymes in the glycolytic pathway. Cell extracts incubated without glucose yielded $0.006 \%$ titratable acidity. We previously showed that $L$. lactis MG1363 is not viable after pressure treatments of 300 to $800 \mathrm{MPa}$ (Malone et al., 2002), corresponding to pressures at which cellular glycolytic capability is inactivated.

Pressurizing $L b$. helveticus at $400 \mathrm{MPa}$ for $10 \mathrm{~min}$ at $30^{\circ} \mathrm{C}$ completely inhibited its acid producing ability (Miyakawa et al., 1994). Pressurizing L. lactis at 200 $\mathrm{MPa}$ for $20 \mathrm{~min}$ at $20^{\circ} \mathrm{C}$ resulted in lower acidification rates when the pressure-treated cells were subsequently incubated in milk (Casal and Gómez, 1999), though the methodology used makes it unclear 


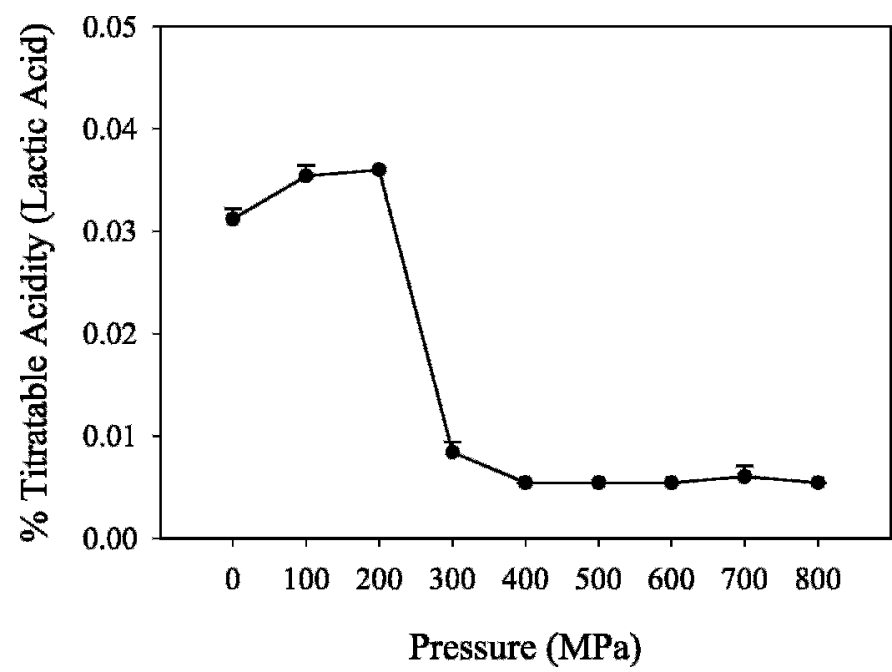

Figure 5. Percent titratable acidity (as lactic acid) produced by cell extracts incubated with glucose. Cell extracts were prepared from Lactococcus lactis MG1363 cells after pressure exposure for 5 min at $25^{\circ} \mathrm{C}$. Error bars represent plus $1 \mathrm{SD}, \mathrm{n} \geq 3$.

whether the decreased acidification rate is due to damage to the glycolytic enzymes specifically or due to a reduced growth rate caused by pressure-induced general cell damage.

\section{Protein Concentrations of Cell Extracts Prepared from Pressure-Treated Cells}

The protein concentrations in lactococcal cell extracts were determined with a Bradford dye-binding assay to standardize the peptidase and CEP enzyme activity assays across pressure treatments. During the course of these experiments, we observed a decrease in protein concentration in the cell extracts with an increase in pressure (Figure 6) though all samples contained approximately the same number of cells. This phenomenon was also reported in tomato extracts (Shook et al., 2001). Possible explanations include: 1) an apparent decrease in protein concentration due to a change in the dye binding capacity of proteins postpressure treatment or 2) an actual decrease in protein concentration caused by aggregation or insolubility of pressure-denatured proteins that are subsequently removed by centrifugation during cell extract preparation. To ensure proper standardization of enzyme activities, we confirmed the cell extract protein concentrations by total nitrogen analysis on cell extracts from $0.1-, 400-$, and $800-\mathrm{MPa}$ treated cells. The nitrogen analysis revealed a similar decrease in protein concentration with increasing pressure as observed with the dye-binding assay (data not shown). The protein concentration in cell extracts was

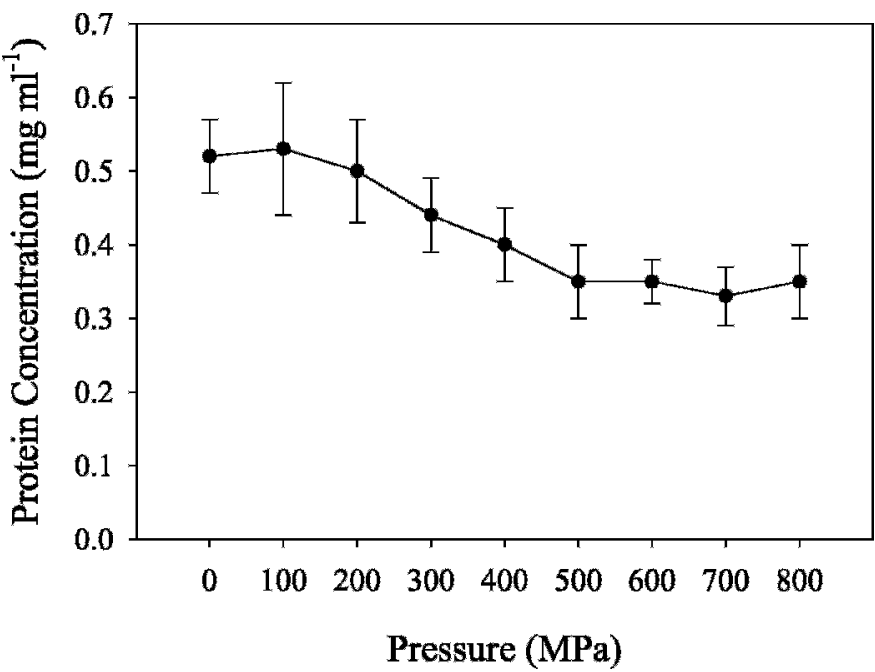

Figure 6. Protein concentration $\left(\mathrm{mg} \mathrm{ml}^{-1}\right)$ in cell extracts from pressure-treated cells determined using the Bio-Rad protein assay. Values are mean $\pm 1 \mathrm{SD}(\mathrm{n}=12)$.

dependent on pressure, and the pressure dependency was not statistically different between the Bradford and total nitrogen assays. Thus, the variations in protein concentration we observed were not an artifact of the protein quantification method used and are likely due to removal of denatured, aggregated proteins during cell extract preparation.

\section{CONCLUSIONS}

Applications of HPP to cheese may include acceleration, arrest, or modulation of cheese ripening and production of attenuated starters with modified peptidolytic capabilities. The present study investigated the effect of pressure on several enzymes involved in Cheddar cheese ripening. Plasmin is recalcitrant to inactivation by any pressure. Chymosin activity is unaffected up to $400 \mathrm{MPa}$ and decreased by $50 \%$ after an $800 \mathrm{MPa}$ treatment. Depending on the pressure treatment, L. lactis proteolytic and glycolytic enzymes could be activated, inactivated, or unaffected. A summary of the effect of different pressures on the enzymes studied is presented in Table 1 .

Pressure treatment at $300 \mathrm{MPa}$ or higher may provide a new method for attenuation of starter cultures. Acid production by cell extracts was abolished by treatments of 300 to $800 \mathrm{MPa}$, yet most peptidases studied retained activity after a $300 \mathrm{MPa}$ exposure, and two aminopeptidases retained activity at 400 to $800 \mathrm{MPa}$ (Table 1). Using attenuated starters with selectively activated or inactivated proteolytic en- 
Table 1. Summary of changes in enzyme activity due to high pressure exposure.

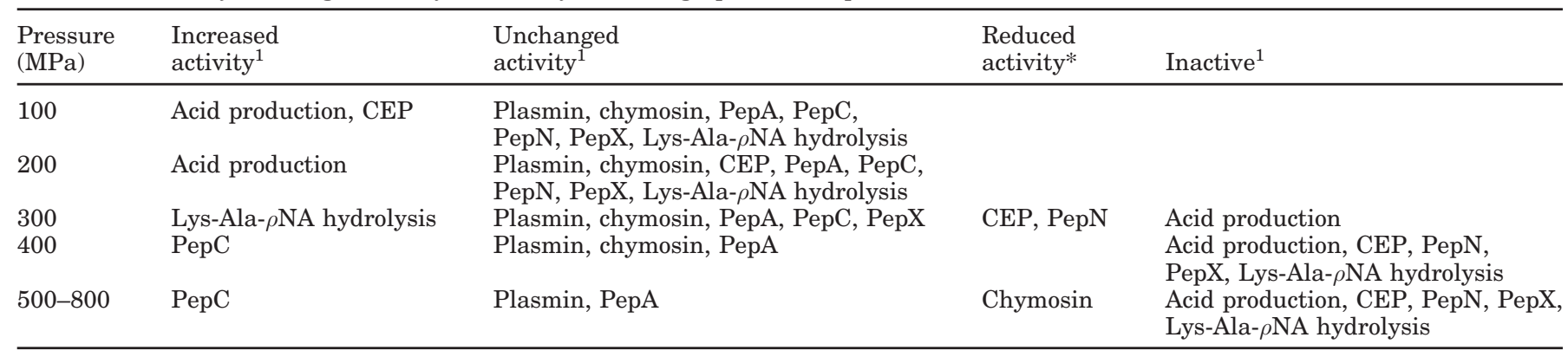

${ }^{1}$ Relative activity are in comparison to the non-pressure-treated control.

zymes may provide new variations in the flavor profiles generated by these additives.

The present study has implications for pressuretreated cheese. We demonstrated that pressure has different effects on different enzymes. Thus, pressure treatment of young cheeses will likely alter the active enzyme profiles, potentially changing the flavor profile of the resulting ripened cheese. HPP may provide a novel way by which the flavor of cheeses can be manipulated. Additional research is required to determine if Cheddar cheese ripening can be manipulated positively by pressure treatment of young cheeses.

\section{ACKNOWLEDGMENTS}

The authors gratefully acknowledge financial support from Dairy Management, Inc. The authors thank W. James Harper, Macdonald Wick, and Uwe Nienaber for helpful discussions. Salaries and additional research support were provided by State and Federal funds appropriated to the Ohio Agricultural Research and Development Center, The Ohio State University.

\section{REFERENCES}

Anese, M., M. C. Nicoli, G. Dall'aglio, and C. R. Lerici. 1995. Effect of high-pressure treatments on peroxidase and polyphenoloxidase activities. J. Food Biochem. 18:285-293.

Boutrou, R., A. Sepulchre, G. Pitel, C. Durier, L. Vassal, J. C. Gripon, and V. Monnet. 1998. Lactococcal lysis and curd proteolysis: Two predictable events important for the development of cheese flavor. Int. Dairy J. 8:609-616.

Bradford, M. M. 1976. A rapid and sensitive method for the quantitation of microgram quantities of protein utilizing the principle of protein-dye binding. Anal. Biochem. 72:248-254.

Cano, M. P., A. Hernandez, and B. D. Ancos. 1997. High pressure and temperature effects on enzyme inactivation in strawberry and orange products. J. Food Sci. 62:85-88.

Casal, V., and R. Gómez. 1999. Effect of high pressure on the viability and enzymatic activity of mesophilic lactic acid bacteria. J. Dairy Sci. 82:1092-1098.

Cheftel, J.-C. 1992. Effects of high hydrostatic pressure on food constituents: An overview. Pages 195-209 in High-Pressure and Biotechnology. C. Balny, R. Hayashi, K. Heremans and P. Masson, ed. Colloque INSERM/John Libbey Eurotext Ltd., France.
Christensen, J. E., E. G. Dudley, J. A. Pedersen, and J. Steele. 1999. Peptidases and amino acid catabolism in lactic acid bacteria. Antonie Van Leeuwenhoek 76:217-246.

Exterkate, F. A., and G. J. C. M. DeVeer. 1987. Purification and some properties of a membrane-bound aminopeptidase A from Streptococcus cremoris. Appl. Environ. Microbiol. 53:577-583.

Fox, P. F., J. M. Wallace, S. Morgan, C. M. Lynch, E. J. Niland, and J. Tobin. 1996. Acceleration of cheese ripening. Antonie Van Leeuwenhoek 70:271-297.

García-Risco, M. R., E. Cortés, A. V. Carrascosa, and R. López-Fandiño. 1998. Microbiological and chemical changes in high-pressure treated milk during refrigerated storage. J. Food Prot. 61:735-737.

Gasson, M. J. 1983. Plasmid complements of Streptococcus lactis NCDO 712 and other lactic streptococci after protoplast-induced curing. J. Bacteriol. 154:1-9.

Gomes, M. R. A., and D. A. Ledward. 1996. Effect of high-pressure treatments on the activity of some polyphenoloxidases. Food Chem. 56:1-5.

Goodner, J. K., R. J. Braddock, and M. Parish. 1998. Inactivation of pectinesterase in orange and grapefruit juices by high pressure. J. Agric. Food Chem. 46:1997-2000.

Kunji, E. R., I. Mierau, A. Hagting, B. Poolman, and W. N. Konings. 1996. The proteolytic systems of lactic acid bacteria. Antonie Van Leeuwenhoek 70:187-221.

Law, B. A. 2001. Controlled and accelerated cheese ripening: The research base for new technologies. Int. Dairy J. 11:383-398.

Malone, A. S., T. H. Shellhammer, and P. D. Courtney. 2002. High pressure effects on the viability, morphology, lysis and cell wall hydrolase activity of Lactococcus lactis subsp. cremoris. Appl. Environ. Microbiol. 68:4357-4363.

Martin, P., J.-C. Collin, P. Garnot, B. R. Dumas, and G. Mocquot. 1981. Evaluation of bovine rennets in terms of absolute concentrations of chymosin and pepsin A. J. Dairy Res. 48:447-456.

Messens, W., J. Estepar-Garcia, K. Dewettinck, and A. Huyghebaert. 1999. Proteolysis of high pressure-treated Gouda cheese. Int. Dairy J. 9:775-782.

Mierau, I., E. R. Kunji, K. J. Leenhouts, M. A. Hellendoorn, A. J. Haandrikman, B. Poolman, W. N. Konings, G. Venema, and J. Kok. 1996. Multiple-peptidase mutants of Lactococcus lactis are severely impaired in their ability to grow in milk. J. Bacteriol. 178:2794-2803.

Miyakawa, H., K. Anjitsu, N. Ishibashi, and S. Shimamura. 1994. Effects of pressure on enzyme activities of Lactobacillus helveticus LHE-511. Biosci. Biotech. Biochem. 58:606-607.

Neviani, E., C. Y. Boquien, V. Monnet, L. Phan Thanh, and J. C. Gripon. 1989. Purification and characterization of an aminopeptidase from Lactococcus lactis subsp. cremoris AM2. Appl. Environ. Microbiol. 55:2308-2314.

Niven, G. W. 1991. Purification and characterization of aminopeptidase A from Lactococcus lactis subsp. lactis NCDO712. J. Gen. Microbiol. 137:1207-1212.

Ohmiya, K., K. Fukami, S. Shimizu, and K. Gekko. 1987. Milk curdling by rennet under high pressure. J. Food Sci. 85:84-87. 
O'Reilly, C. E., P. M. O'Connor, A. L. Kelly, T. P. Beresford, and P. M. Murphy. 2000. Use of high hydrostatic pressure for inactivation of microbial contaminants in cheese. Appl. Environ. Microbiol. 66:4890-4896.

Salesse, R., and J. Garnier. 1976. Synthetic peptides for chymosin and pepsin assays: $\mathrm{pH}$ effect and pepsin independent-determination in mixtures. J. Dairy Sci. 59:1215-1221.

Scollard, P. G., T. P. Beresford, P. M. Murphy, and A. L. Kelly. 2000. Barostability of milk plasmin activity. Le Lait 80:609-619.

Shook, C. M., T. H. Shellhammer, and S. J. Schwartz. 2001. Polygalacturonase, pectinesterase, and lipoxygenase activities in high- pressure-processed diced tomatoes. J. Agric. Food Chem. 49:664-668

Tan, S. T., and W. N. Konings. 1990. Purification and characterization of aminopeptidase from Lactococcus lactis subsp. cremoris Wg2. Appl. Environ. Microbiol. 56:526-532.

Terzaghi, B. E., and W. E. Sandine. 1975. Improved medium for lactic streptococci and their bacteriophages. Appl. Environ. Microbiol. 29:807-813.

Vesanto, E., K. Savijoki, T. Rantanen, J. L. Steele, and A. Palva. 1995. An X-prolyl dipeptidyl aminopeptidase (pepX) gene from Lactobacillus helveticus. Microbiol. 141:3067-3075. 